\title{
DETERMINANTS OF CREDIT RISK
}

\author{
Dr. K. Riyazahmed \\ Assistant Professor \\ Shri Dharmasthala Manjunatheshwara \\ Institute for Management Development \\ Mysore, Karnataka, India \\ E-mail: riyazahmed@sdmimd.ac.in \\ Dr. Gunja Baranwal \\ Assistant Professor \\ Alliance School of Business \\ Alliance University, Bangalore, Karnataka, India \\ E-mail: baranwalgunja@gmail.com
}

\begin{abstract}
This study aims to empirically examine the impact of managerial effectiveness on the credit risk of the Indian public and private sector banks. We consider the return on assets as a proxy for managerial effectiveness and gross non-performing assets (GNPA) to total advances as a proxy for credit risk. The study uses fixed effects and dynamic panel data models to examine the impact. The econometric model estimations suggest a negative impact of return on assets on credit risk. Further, we analyze the impact of return on assets by the information of microeconomic and macro-economic variables in dynamic generalized methods of moments (GMM) approach. The results remain the same after using dynamic GMM modelled with lagged credit risk and lagged return on assets. Further, the effect of macroeconomic variables such as repo rate and reverse repo rate confirms the theory. Heterogeneity checks at regions and sector levels substantiate the robustness of results.
\end{abstract}

Keywords: Credit Risk, Non-Performing Assets, Loan Defaults, GMM Model, Dynamic Effects.

JEL Classification Codes: G20, G21.

Acknowledgment: We thank Mr. Balachandar Kaliappan, TUM School of Management, Munich, Germany, for giving his valuable suggestions for the research paper.

\section{INTRODUCTION}

Non-performing assets (NPA) in the balance sheets of Indian banks are piling up, resulting in capital insufficiency, breaching regulatory requirements \& worsening credit risk. Such an NPA scenario will ultimately result in a nationwide credit crisis (Valencia \& Laeven, 2008). In the past, bank-credit-driven global economic crisis - 2007 made economists and regulators look deeper into the factors driving credit risk, particularly in the banking sector (Castro, 2013).

To effectively manage the financial stability of Indian banks, understanding credit risk is a matter of utmost importance. To protect the real sectors from economic collapse, controlling the factors causing credit risk is an immediate necessity (Salas \& Saurina, 2002). 
Gulati, Goswami, and Kumar (2019); Das and Ghosh (2007) and Digal, Satpathy, and Behera (2015) are the few notable research works focused on credit risk in the Indian context. However, the data considered for their study covers only up to the year 2010. Since 2010 the Indian economy and banking sector has seen drastic changes which in turn cause a change in credit risk. Reserve Bank of India statistics (Table_1) shows a steep increase in the credit risk of Indian banks during the past five years. So, an empirical analysis with the recent data is essential to efficiently manage credit risk. Various factors impact credit risk. In this study, we focus on one of the major managerial efficiency factors, Return on Assets (ROA) a ratio of operating profit to average total assets. As a financial performance metric, ROA reflects the ability of a bank's management to generate profits from the bank's assets (Athanasoglou, Delis, \& Staikouras, 2006). So, we believe the ability of the banks to generate profit (ROA) should effectively help reduce the non-performing assets (i.e., credit risk). In this study, we examine the impact of ROA on credit risk with various other macroeconomic, bank-specific, industry-specific factors using the data from the year 2010 to 2018.

At first, we use fixed effects and Generalized Methods of Moments (GMM) estimation approach to identify the impact of ROA on credit risk. Macroeconomic, bankspecific, and industry-specific variables are also included to examine their impact on credit risk because lending standards in banks are driven by industry practices and level of competition. Besides, the effect of region and ownership of the bank is also tested in the study, to examine the significant difference in impact due to the region of operation and ownership. In the final model with dynamic GMM estimation, we have included lagged credit risk and lagged ROA in addition to the above-mentioned variables.

Table 1. Trends in Gross Non-Performing Assets ratios in the Indian Banking Industry

\begin{tabular}{|l|l|l|l|}
\hline Year & $\begin{array}{l}\text { Public Sector } \\
\text { Banks }\end{array}$ & $\begin{array}{l}\text { Private Sector } \\
\text { Banks }\end{array}$ & $\begin{array}{l}\text { All } \\
\text { Commercial Banks }\end{array}$ \\
\hline 2010 & 2.03 & 2.99 & 2.42 \\
\hline 2011 & 1.97 & 2.48 & 2.35 \\
\hline 2012 & 2.67 & 2.09 & 2.95 \\
\hline 2013 & 3.24 & 1.77 & 3.23 \\
\hline 2014 & 4.09 & 1.78 & 3.83 \\
\hline 2015 & 5.26 & 2.1 & 4.27 \\
\hline 2016 & 10.7 & 2.8 & 7.5 \\
\hline 2017 & 12.95 & 4.05 & 9.32 \\
\hline 2018 & 14.58 & 4.62 & 11.18 \\
\hline
\end{tabular}

Source: Author's calculation based on RBI data

Figure 1. Credit Risk of Indian Banks

The findings of this study are highly important for policymakers, bank management, and researchers to better understand credit risk. Besides, it contributes to the existing literature by examining a wide range of factors driving credit risk in the Indian context particularly in the years 2010-2018, during which no study has been conducted.

The paper has been divided into the following. Section 2 presents the literature review. Section 3, about the methodology. Section 4 focuses on data analysis and interprets the results. The last section summarizes the conclusion of the research work.

\section{LITERATURE REVIEW}

Credit risk refers to the risk associated with any kind of default on credit-linked events, such as changes in the credit quality (including downgrades or upgrades in credit ratings), 
variations of credit spreads, and the default event (Bielecki \& Rutkowski, 2004). In this study, by credit risk we mean the non-payment of loans by borrowers of commercial banks, i.e the default event. In between 2001 -2010 research studies have focused on the impact of mainly the macro-economic factors on credit risk (Bielecki \& Rutkowski, 2004; Tang \& Yan, 2006; Hofmann, 2005). However, a few studies have focused on the impact of bank-specific factors on credit risk in recent years (Gulati et al., 2019; Ghenimi, Chaibi, \& Omri, 2017).

Research works of Castro (2013) and Nkusu (2011) found that gross domestic product (GDP), inflation, stock market, and the exchange rate influencing credit risk. A research study by Turan (2016) found that credit risk is determined by global competition, firm bankruptcy, the increment in credit, and the decline in profit margin and credit derivative products.

A research study by Manab, Theng, and Rus (2015) found that liquidity, profitability, and productivity ratio are significant in impacting credit risk. Besides, a research study by Yurdakul (2014) adds that growth rate and ISE stock market index reduces banks' credit risk in the long run, while money supply, foreign exchange rate, unemployment rate, inflation rate, and interest rate increase credit risk. A research study by Salas and Saurina (2002) used the GMM approach to analyze the determinants of credit risk. They found that GDP growth rate, rapid past credit, branch expansion, portfolio composition, size, net interest margin, capital ratio, and market power significantly explains credit risk.

Research paper by Gulati et al. (2019) has studied the impact of macro-economic variables real namely GDP growth rate, inflation rate, real effective exchange rate and bankspecific variables like bank profitability, income diversification, credit growth, bank size, and cost inefficiency, industry-specific variables like concentration ratio, on the changes in NPA. Besides, they found the impact of management or ownership, prudential norms, and financial crisis on credit risk. This is a significant contribution to the existing literature in the Indian context. However, the period taken for the study is from 1999 to 2014, which does not cover the data of the past 5 years, which is to be critically examined because of the significant rise in the big-ticket loan defaults.

\section{Data}

\section{METHOD}

The bank-level data used for the study is taken from the year-end (March) financial reports for a period of 9 years from 2010 to 2018. These are extracted from Capitaline, a digital corporate database of Indian companies with a structured and systematic presentation of financial data. A total of 40 banks are considered for analysis excluding five banks that do not have complete data over the period taken for the study. Data related to macro-economic factors are taken from RBI publications and India Stat, India's largest e source of socioeconomic statistical data.

\section{Variables}

Credit risk is the dependent variable, and it is predicted by several independent variables taken for the study, which are grouped into macroeconomic variables, bank-specific variables, industry variables, and a dummy variable (Table A2).

\section{Macro-economic variables}

Macro-economic variables are most important in impacting credit risk. Nkusu (2011) and Castro (2013) found that the GDP growth rate affects credit risk. They point out that when GDP growth decreases bank credit risk increases. Gross Value-Added growth rate (GVA) is used in this study.

GVA is an alternate to Gross domestic product and a better measure since it includes 
all primary incomes (Cai \& Leung, 2020). Gulati et al. (2019), Ghenimi et al. (2017), Yurdakul (2014), Bhattarai (2019) found that the Inflation rate broadly affects credit risk. Khemraj and Pasha (2009) argue that appreciation in domestic currency will reduce the financial health of exporting firms and in turn reduce their debt-servicing capacity, which will result in loan defaults. So, like the inflation rate, we can expect a positive impact of the Real Effective Exchange Rate (REER) on credit risk.

In addition to the above macro variables, the repo rate, and reverse repo rate are included in this study. We hypothesize the negative impact of both repo and reverse repo on the credit risk since an increase in both variables will reduce money supply or loan lending and thereby reducing credit risk.

\section{Bank specific variables}

The profitability of the banks can be determined by their ROA, which primarily shows the managerial efficiency in generating returns. Higher ROA signals greater financial health to face shocks and it is related to credit risk. Bhattarai (2018) found that ROA is significant in impacting Non-Performing Assets. Likewise, Gulati et al. (2019) and Ghenimi et al. (2017) found that higher profitability lowers credit risk. So, we hypothesize a negative impact of ROA on credit risk.

Income diversification is evident in the banking industry as all the banks are now involved in non-traditional banking activities like investment banking, assets management, insurance, underwriting, etc. Revenue from these businesses is normally classified as NonInterest income (NOI). This includes fees rather than interest. Gulati et al. (2019) point out that more diversification leads to an increase in the probability of credit risk. So, we expect a negative impact of non-interest income in the credit risk. The ratio of non-interest income to total income is used as a measure of income diversification.

Credit growth is considered one of the important influencers in credit risk. We understand that acquiring more business banks reduces the credit standards and interest rates which automatically leads to a decrease in the quality of the loans and eventually ends up as NPA. Gulati et al. (2019) and Salas and Saurina (2002) found that higher credit growth increases the probability of defaults in the banking sector. So, we hypothesize a negative impact of credit growth on credit risk. In this study, we use loans to total assets as a proxy for credit growth.

The size of the bank plays important role in impacting credit risk. The bigger the size the more the ability of the banks to systemize the loan procedures and thereby reduce the credit risk. In contrast, Ranjan and Dhal (2003) found that bank size negatively affects credit risk. The reason is large banks leverage too much to acquire more business and thereby reduces the quality of loans to substandard borrowers. With this view, in this study, we hypothesize a negative impact of bank size on credit risk.

Cost efficiency is generally captured by the ratio of operating expenses to total assets. Ghosh (2015) and Vasishtha and Rajaraman (2002) found a negative impact on cost efficiency on bad loans. More efficiency of the management to control cost lesser the banks' chance of ending with bad loans. So, we expect a negative relationship between cost efficiency and credit risk. In addition to the variables mentioned above, we have taken the age of the bank and business per employee to test their significance in impacting the credit risk. We hypothesize the negative impact of both the factors on credit risk since banks with longer business operations would follow standard lending practices and the efficiency of employees also will reduce the credit risk.

\section{Industry-specific variable}

Concentration risk is represented by the concentration ratio. It refers to the degree of market 
concentration. The more the concentration of the markets by a few banks, the lesser will be the competition. Gulati et al. (2019) point out that lesser competition leads to charging higher interest, thereby results in credit risk. In this study, as considered by Gulati et al. (2019), the share of advances by the 10 largest banks is taken as a concentration ratio. We hypothesize a negative impact of concentration on credit risk.

\section{Dummy variable - Political regime}

During the period taken for the analysis, the country has faced two political regimes showing the difference in credit risk control measures. So as a new factor, the Political regime is included in the model as a dummy variable to study the significance of its impact on reducing credit risk. We hypothesize a negative impact since the changed regime would take measures to reduce the credit risk.

\section{Model}

Our baseline model looks like equation (1) where we examine the effect of return on assets on credit risk along with various other explanatory variables.

$\mathrm{Y} \_\mathrm{it}=\alpha \_\mathrm{i}+\llbracket \beta \_1 \rrbracket \_$it $\llbracket \mathrm{X} \_1 \rrbracket \_\mathrm{it}+\beta_{-} \mathrm{itZ} \_\mathrm{it}+\varepsilon_{-}$it

Where ' $i$ ' refers to bank and ' $t$ ' refers to the year

$Y \_$it $=$credit risk

$\mathrm{X} \_\mathrm{it}=$ return on assets

Z_it consists of a list of the micro variables like business per employee, cost efficiency, age of banks, non-interest income, concentration ratio, size, credit growth, and macro variables like the repo rate, reverse repo, gross value-added growth rate, wholesale price index, real effective exchange rates, and political regime.

\section{Problem of endogeneity}

Although we could get the estimates of the effect of ROA on credit risk with a host of other explanatory variables, there is one problem associated with this equation simply defies viz. the problem of endogeneity, the correlation between variables in the model. It is a potential anomaly in econometric models, which may cause inconsistent parameter estimates (Guerrero, Guevara, and Cherchi, 2020). This problem creates spurious estimates of $\beta$ 's in equation (1).

Endogeneity appears in equation (1) due to the dependence of return on assets on credit risk in the banking sector. As pointed out, this will also cause biased estimates of $\beta$ parameters by ignoring the dependence of return on assets on credit risk. Arellano and Bond (1991) provide a solution to this problem using the following equation:

$$
\begin{aligned}
& Y_{i t}=\beta_{1} X_{i t}+\beta_{2} W_{i t}+v_{i t} \\
& v_{i t}=u_{i}+\epsilon_{i t} \ldots \ldots \ldots \ldots
\end{aligned}
$$

Where 'i' refers to the bank and 't' refers to the year.

Equation (2) divides the explanatory variables of equation (1) into two parts that are exogenous and endogenous. Where $\boldsymbol{X}_{\boldsymbol{i t}}$ it incorporates our list of exogenous variables and 
$\boldsymbol{W}_{i t}$ hosts a list of endogenous variables. The list of exogenous variables does not depend upon gross non-performing assets whereas the list of endogenous variables includes the variables which may be dependent upon the value of gross non-performing assets. $\boldsymbol{W}_{i t} \mathrm{~h}$ also incorporates the lag of the dependent variable thus removing the possible correlation with the error term $\boldsymbol{u}_{\boldsymbol{i}}$. This is required to eliminate any autocorrelation between the current value of the dependent variable to its previous year values.

Thus, in our estimation equation, $\boldsymbol{X}_{\boldsymbol{i t} \_}$it includes all the macro-level variables like repo rate, reverse repo rate, gross value-added growth rate, wholesale price index, and real effective exchange rate. Since these are all macro-level variables, which are included in the equation as exogenous variables, they should remain unaffected by the value of the dependent variable.

The endogenous variables are bank-specific variables like return on assets, cost inefficiency, age, non-interest income, concentration ratio, size, credit growth, and business per employee, which are included in $\boldsymbol{W}_{\boldsymbol{i t}}$. Gulati et.al (2019) also use various endogenous bank-specific and exogenous macro-economic variables in a dynamic GMM setup. Baranwal (2018) also use a list of macro-economic variables as exogenous variables though in a different context.

Table 2. selected studies on the determinants of credit risk in the banking sector

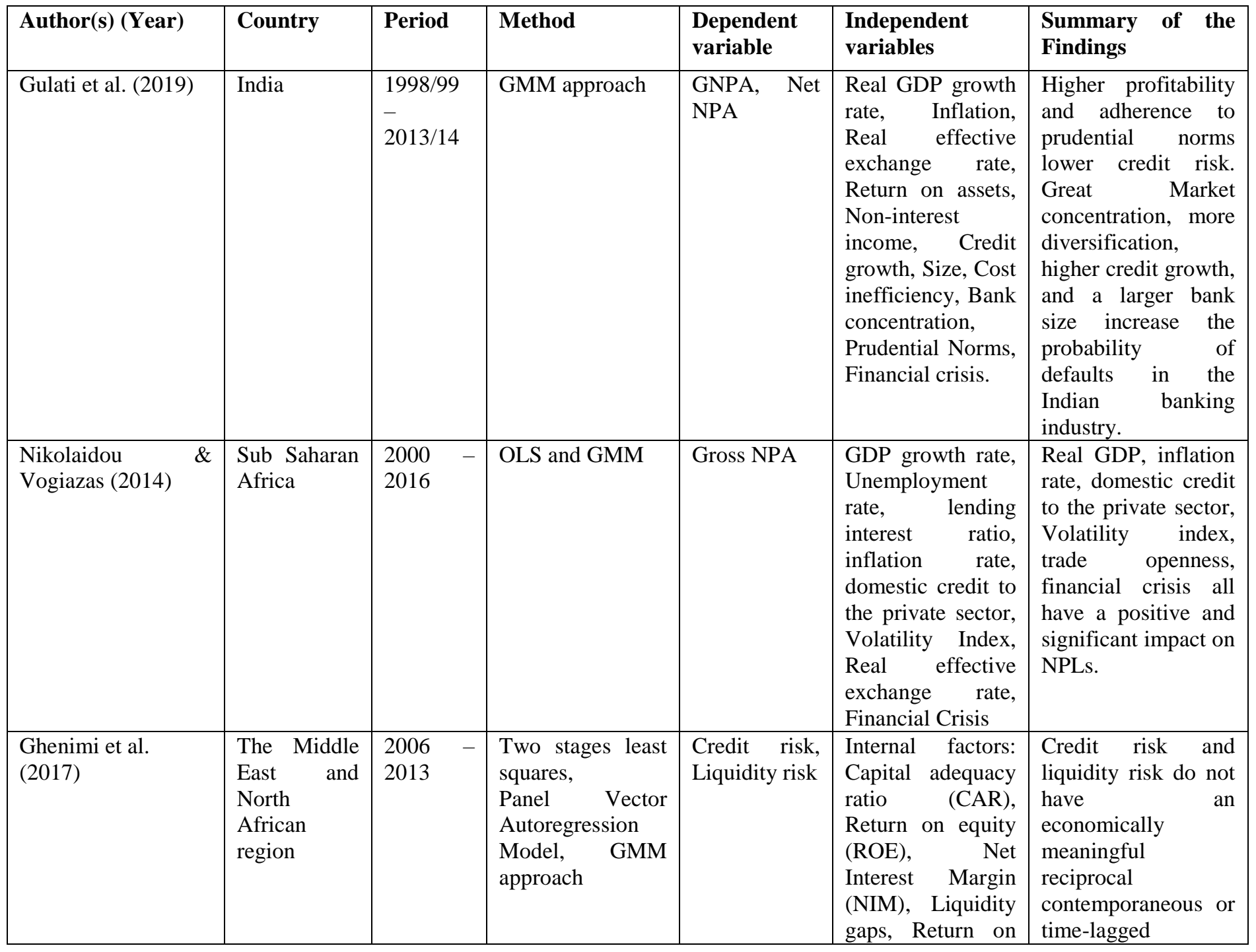




\begin{tabular}{|c|c|c|c|c|c|c|}
\hline & & & & & $\begin{array}{l}\text { assets (ROA), } \\
\text { Size of the banks, } \\
\text { loan growth, crisis } \\
\text { dummy, loan } \\
\text { assets, efficiency, } \\
\text { Income diversity. } \\
\text { External Factors: } \\
\text { Inflation rate, } \\
\text { GDP. }\end{array}$ & $\begin{array}{l}\text { relationship; besides, } \\
\text { each risk category } \\
\text { has a significant } \\
\text { impact on banking } \\
\text { stability }\end{array}$ \\
\hline Turan (2016) & Turkey & 2015 & $\begin{array}{l}\text { Analytical } \\
\text { Hierarchy Process } \\
\text { Method, } \\
\text { Consistency ratio }\end{array}$ & - & - & $\begin{array}{l}\text { The factors affecting } \\
\text { Credit risk has six } \\
\text { subfactors. These } \\
\text { are global } \\
\text { competition, firm } \\
\text { bankruptcy, the } \\
\text { increment in credit } \\
\text { customers, and the } \\
\text { decline in profit } \\
\text { margin, credit } \\
\text { derivative products, } \\
\text { and other risks. }\end{array}$ \\
\hline Misman et al. (2015) & Malaysia & $\begin{array}{l}1995 \\
2013\end{array}$ & $\begin{array}{l}\text { Panel data } \\
\text { analysis, Random } \\
\text { Effects } \\
\text { Generalised least } \\
\text { square (RE-GLS) }\end{array}$ & Gross NPL & $\begin{array}{l}\text { Financing } \\
\text { expansion, } \\
\text { financing quality, } \\
\text { Capital buffer, } \\
\text { Capital ratio, Net } \\
\text { interest margin, } \\
\text { Management } \\
\text { Efficiency, Log of } \\
\text { total assets. }\end{array}$ & $\begin{array}{l}\text { Financing quality } \\
\text { and capital buffer } \\
\text { have a significant } \\
\text { impact on credit risk } \\
\text { in all models. }\end{array}$ \\
\hline Manab et al. (2015) & Malaysia & $\begin{array}{ll}2006 & - \\
2012 & \end{array}$ & $\begin{array}{l}\text { Logistic } \\
\text { regression }\end{array}$ & $\begin{array}{l}\text { Bankruptcy } \\
\text { ratio }\end{array}$ & $\begin{array}{l}\text { Liquidity ratio, } \\
\text { productivity ratio, } \\
\text { profitability ratio, } \\
\text { leverage ratio. }\end{array}$ & $\begin{array}{l}\text { Liquidity, } \\
\text { profitability, and } \\
\text { productivity ratio are } \\
\text { significant } \\
\text { impacting } \\
\text { bankruptcy }\end{array}$ \\
\hline Yurdakul (2014) & Turkey & $\begin{array}{ll}1998 & - \\
2012\end{array}$ & $\begin{array}{l}\text { General } r \\
\text { specific } \\
\text { modeling, Credit } \\
\text { portfolio view } \\
\text { model, Gregory } \\
\text { Hansen Method }\end{array}$ & NPL & $\begin{array}{l}\text { GDP growth rate, } \\
\text { Inflation rate, ISE } \\
-\quad 100 \text { indexes, } \\
\text { unemployment } \\
\text { rate, exchange } \\
\text { rate, nominal } \\
\text { deposit interest } \\
\text { rate, } \\
\text { percentage and } \\
\text { changes in M2. }\end{array}$ & $\begin{array}{l}\text { Growth rate and ISE } \\
\text { index are the } \\
\text { variables that reduce } \\
\text { banks' credit risk in } \\
\text { the long run, while } \\
\text { money supply, } \\
\text { foreign exchange } \\
\text { rate, unemployment } \\
\text { rate, inflation rate, } \\
\text { and interest rate are } \\
\text { the variables that } \\
\text { increase banks' } \\
\text { credit risks }\end{array}$ \\
\hline Curak et al. (2012) & Macedonia & $\begin{array}{l}2005- \\
2010\end{array}$ & $\begin{array}{lr}\begin{array}{l}\text { Dynamic } \\
\text { analysis } \\
\text { technique) }\end{array} & \end{array}$ & ROA & $\begin{array}{l}\text { Credit risk, } \\
\text { solvency risk, } \\
\text { bank size, } \\
\text { liquidity risk, fee } \\
\text { income, operating } \\
\text { expenses, } \\
\text { management, } \\
\text { concentration, } \\
\text { EBRD index, } \\
\text { GDP growth }\end{array}$ & $\begin{array}{l}\text { Among internal } \\
\text { factors of bank } \\
\text { profitability, the } \\
\text { most important one } \\
\text { is operating expense } \\
\text { management. } \\
\text { Further, profitability } \\
\text { is influenced by } \\
\text { solvency risk and } \\
\text { liquidity risk. } \\
\text { Regarding the }\end{array}$ \\
\hline
\end{tabular}




\begin{tabular}{|c|c|c|c|c|c|c|}
\hline & & & & & & $\begin{array}{lr}\text { external } & \text { variables, } \\
\text { economic } & \text { growth, } \\
\text { banking } & \text { system } \\
\text { reform, } & \text { and } \\
\text { concentration } & \text { show } \\
\text { a significant } & \text { effect } \\
\text { on } & \text { bank } \\
\text { profitability. } & \end{array}$ \\
\hline $\begin{array}{l}\text { Salas and Saurina } \\
(2002)\end{array}$ & Spain & $\begin{array}{l}1985- \\
1997\end{array}$ & GMM approach & Gross NPA & $\begin{array}{l}\text { GDP growth rate, } \\
\text { size, net interest } \\
\text { margin, branch } \\
\text { expansion, capital } \\
\text { ratio, market } \\
\text { power, past credit, } \\
\text { inflation, ROA, } \\
\text { ROE. }\end{array}$ & $\begin{array}{l}\text { GDP Growth rate, } \\
\text { rapid past credit, } \\
\text { branch expansion, } \\
\text { portfolio } \\
\text { composition, size, } \\
\text { net interest margin, } \\
\text { capital ratio, and } \\
\text { Market power are } \\
\text { the variables that } \\
\text { explain credit risk. }\end{array}$ \\
\hline $\begin{array}{l}\text { Vasishtha and } \\
\text { Rajaraman (2002) }\end{array}$ & India & $\begin{array}{l}1995- \\
2000\end{array}$ & $\begin{array}{l}\text { Multiple } \\
\text { Regression, } \\
\text { Housman test }\end{array}$ & Gross NPA & $\begin{array}{l}\text { Operating profit } \\
\text { to working funds } \\
\text { (Time effect, } \\
\text { Group effect) }\end{array}$ & $\begin{array}{l}\text { Banks with higher- } \\
\text { than-average NPAs } \\
\text { are explained by } \\
\text { poor operating } \\
\text { efficiency. }\end{array}$ \\
\hline
\end{tabular}

Source: Author's elaboration

\section{RESULTS \& DISCUSSION}

\section{Fixed effects}

We start by estimating our model (equation 1) with fixed effects. Table 3 presents the results of fixed effects. We start by estimating our model (equation 1) with fixed effects. Table 3 presents the results of the fixed effects estimation. We try different specifications of the model. In Model 1, we have taken only micro variables. We find that the return on assets is negatively related to credit risk. One unit increase in return on assets causes 2.8 units to decrease in credit risk. The coefficient of concentration ratio is also found to be negative. A higher concentration of businesses will result in higher interest rates due to lesser competition thus results in increased credit risk.

Cost efficiency is negatively related to credit risk. It may be because an increase in operating efficiency by a reduction in operating expenses leads to a reduction in credit risk. The coefficient of non-interest income is found to be positive. One unit increase in noninterest income causes 2.9 units to change in credit risk. This may occur due to the diversification of bank's incomes leading to lesser loan defaults. The other variables like credit growth and business per employee do not show a significant impact on credit risk. Thus, we do not find any loan quality deterioration effect of an increase in credit.

In the next model (Model 2), we test the effect of macro-economic variables on credit risk. The coefficient of return of assets now decreases from -2.8 to -3.4. In macro variables, we find a negative effect of repo rate on credit risk. One-unit increase repo rate leads to a decrease in credit risk by 9.4 units. The results are in line with the theory that if the loans become more expensive due to a higher repo rate, the lending will fall leading to a further fall in the credit risk. The opposite is true for the reverse repo rate which will increase the credit risk. When the central bank increases reverse repo, banks might increase lending rates since it is more profitable to invest in reverse repo government securities than lending money as loans. A higher lending rate would cause higher loan defaults. As expected, we find that one unit increase in the reverse repo rate is related to a 10.8 unit increase in credit risk.

The growth rate of gross value added is positively related to credit risk which reflects that as the economy grows the demand for more credit grows which will also result in higher 
credit risk. One unit increase in the GVA growth rate is related to a 2.1 unit increase in credit risk. Whereas inflation is negatively related to credit risk which may be caused by the increase in the cost of credit. So, it is negatively related to credit risk. Another interesting finding is the negative coefficient of change in the political regime. It shows that with the arrival of a new government the extent of credit risk has reduced by 0.5 units in comparison to the previous government.

In model 3, we incorporate both the micro and macro variables (repo and reverse repo rates only) simultaneously. The results remain the same. The coefficient of the repo and reverse repo reduce to -2.3 and 2.33 respectively. In model 4 , we consider the full list of micro and macro variables. The significance of variables is robust to the changes in specifications in models.

Table 3. Effect of micro and macro-economic variables on credit risk (Fixed effects estimation)

\begin{tabular}{|c|c|c|c|c|}
\hline & Model 1 & Model 2 & Model 3 & Model 4 \\
\hline VARIABLES & Credit risk & Credit risk & Credit risk & Credit risk \\
\hline \multirow[t]{2}{*}{ Return on assets } & $-2.811 * * *$ & $-3.425 * * *$ & $-2.800 * * *$ & $-2.796 * * *$ \\
\hline & $(-0.591)$ & $(-0.532)$ & $(-0.685)$ & $(-0.689)$ \\
\hline \multirow[t]{2}{*}{ Cost efficiency } & $229.910^{* *}$ & & $315.024 * *$ & $314.873 * *$ \\
\hline & $(-93.921)$ & & $(-111.65)$ & $(-118.681)$ \\
\hline \multirow{2}{*}{ Age of bank } & $1.236 * * *$ & & $0.860 * * *$ & $0.902 * * *$ \\
\hline & $(-0.254)$ & & $(-0.216)$ & $(-0.192)$ \\
\hline \multirow{2}{*}{$\begin{array}{l}\text { Non-Interest } \\
\text { income }\end{array}$} & $2.934 * * *$ & & $2.465 * * *$ & $2.548 * * *$ \\
\hline & $(-0.543)$ & & $(-0.679)$ & $(-0.649)$ \\
\hline \multirow{2}{*}{$\begin{array}{l}\text { Concentration } \\
\text { risk }\end{array}$} & $0.000 * *$ & & $0.000 * *$ & $0.000 * *$ \\
\hline & 0 & & 0 & 0 \\
\hline \multirow[t]{2}{*}{ Size of the bank } & $-25.364^{*}$ & $-6.430 * * *$ & $-24.472^{*}$ & $-24.601 *$ \\
\hline & $(-11.276)$ & $(-1.084)$ & $(-11.399)$ & $(-11.461)$ \\
\hline \multirow{2}{*}{$\begin{array}{l}\text { Size of the bank } \\
\text { squared }\end{array}$} & 1.611 & & 1.619 & 1.636 \\
\hline & $(-1.366)$ & & $(-1.391)$ & $(-1.398)$ \\
\hline \multirow[t]{2}{*}{ Credit growth } & 5.071 & & 5.699 & 4.647 \\
\hline & $(-8.064)$ & & $(-9.914)$ & $(-10.045)$ \\
\hline \multirow{2}{*}{$\begin{array}{ll}\begin{array}{l}\text { Business } \\
\text { employee }\end{array} & \text { per } \\
\end{array}$} & -0.005 & & 0.019 & 0.013 \\
\hline & $(-0.189)$ & & $(-0.198)$ & $(-0.204)$ \\
\hline \multirow[t]{2}{*}{ Repo rate } & & $-9.467 * * *$ & $-2.344 * * *$ & $-2.415^{*}$ \\
\hline & & $(-2.151)$ & $(-0.639)$ & $(-1.163)$ \\
\hline \multicolumn{2}{|l|}{ Reverse repo rate } & $10.848 * * *$ & $2.337 * * *$ & $2.048 *$ \\
\hline & & $(-2.444)$ & $(-0.463)$ & $(-1.084)$ \\
\hline \multirow{2}{*}{$\begin{array}{ll}\text { Gross } & \text { Value } \\
\text { Added } & \\
\end{array}$} & & $2.142 * * *$ & & -0.19 \\
\hline & & $(-0.6)$ & & $(-0.258)$ \\
\hline \multirow[t]{2}{*}{ Inflation } & & $-0.035 * * *$ & & 0.003 \\
\hline & & $(-0.01)$ & & $(-0.007)$ \\
\hline
\end{tabular}




\begin{tabular}{|l|l|l|l|l|}
\hline Exchange rate & & $-0.386^{* * * *}$ & & -0.027 \\
\hline & & $(-0.113)$ & & $(-0.068)$ \\
\hline Political regime & & $-0.508^{*}$ & -0.154 & 0.082 \\
\hline & & $(-0.239)$ & $(-0.204)$ & $(-0.223)$ \\
\hline Constant & -7.864 & $72.662 * * *$ & 18.87 & 21.898 \\
\hline & -37.472 & $(-12.311)$ & $(-33.53)$ & $(-34.286)$ \\
\hline & & & & \\
\hline Observations & 333 & 342 & 333 & 333 \\
\hline R-squared & 0.741 & 0.721 & 0.752 & 0.753 \\
\hline Number of id & 37 & 38 & 37 & 37 \\
\hline Robust standard errors in parentheses & & \\
\hline$* * * \mathrm{p}<0.01, * * \mathrm{p}<0.05, * \mathrm{p}<0.1$ & & \\
\hline
\end{tabular}

\section{Heterogeneity check}

We checked the robustness of the results. First, we consider the geographical region of the banks. We divide the banks into four geographical regions viz. east, west, north, south, and test the same model with both micro and macro variables. Table 4 shows the region-wise results of the same model. We start with the east region. The return on assets becomes insignificant for this region along with the repo and reverse repo rates. The effect of cost efficiency, concentration ratio, inflation, and exchange rates remain intact.

The west region follows similar results in the fixed effects estimation. The coefficient of return on assets is -2.92 . Cost efficiency and non-interest income have a positive and significant impact on credit risk. The effect of the repo and reverse repo rates also remains the same on credit risk. North and south also have similar results with a negative and significant coefficient of return on assets and concentration ratio. Cost efficiency and non-interest income have a positive and significant effect on credit risk.

Table 4. Region-wise effect of micro and macro-economic variables on credit risk.

\begin{tabular}{|c|c|c|c|c|}
\hline Region & East & West & North & South \\
\hline & (1) & (2) & (3) & (4) \\
\hline VARIABLES & Credit risk & Credit risk & Credit risk & Credit risk \\
\hline \multirow[t]{2}{*}{ Return on assets } & 0.039 & $-2.920 * * *$ & $-3.479 * * *$ & $-2.702 * * *$ \\
\hline & $(0.849)$ & $(0.743)$ & $(0.426)$ & $(0.478)$ \\
\hline \multirow[t]{2}{*}{ Cost efficiency } & $7,250.128 * * *$ & $392.426 * * *$ & $-3,908.339 * *$ & $433.968 * * *$ \\
\hline & $(1,394.089)$ & $(120.202)$ & $(1,421.730)$ & $(142.574)$ \\
\hline \multirow[t]{2}{*}{ Age of the bank } & $-0.092 * * *$ & $0.034 * *$ & -0.028 & $-0.051 * *$ \\
\hline & $(0.022)$ & $(0.017)$ & $(0.019)$ & $(0.022)$ \\
\hline \multirow{2}{*}{$\begin{array}{l}\text { Non-interest } \\
\text { income }\end{array}$} & -2.832 & $0.702 *$ & -2.015 & $4.406 * * *$ \\
\hline & $(2.228)$ & $(0.365)$ & (2.194) & $(1.195)$ \\
\hline \multirow{2}{*}{$\begin{array}{l}\text { Concentration } \\
\text { risk }\end{array}$} & $-0.000 * * *$ & 0.000 & $-0.000^{*}$ & $-0.000 * * *$ \\
\hline & $(0.000)$ & $(0.000)$ & $(0.000)$ & $(0.000)$ \\
\hline \multirow[t]{2}{*}{ Size of the bank } & $-812.327 * *$ & $4.190^{*}$ & $-76.577 * * *$ & $-107.566 * * *$ \\
\hline & $(264.479)$ & $(2.182)$ & $(23.666)$ & $(28.086)$ \\
\hline \multirow{2}{*}{$\begin{array}{l}\text { Size of the bank } \\
\text { squared }\end{array}$} & $88.994 * * *$ & $-0.436 * *$ & $8.727 * * *$ & $12.600 * * *$ \\
\hline & $(27.042)$ & $(0.199)$ & $(2.761)$ & $(3.194)$ \\
\hline
\end{tabular}




\begin{tabular}{|l|l|l|l|l|}
\hline Credit growth & 7.353 & $-9.959^{*}$ & 16.108 & -9.088 \\
\hline $\begin{array}{l}\text { Business per } \\
\text { employee }\end{array}$ & $(19.650)$ & $(5.935)$ & $(17.469)$ & $(8.359)$ \\
\hline & -0.012 & $0.143^{*}$ & 0.231 & $-0.290^{* *}$ \\
\hline Repo rate & $(0.619)$ & $(0.077)$ & $(0.215)$ & $(0.122)$ \\
\hline & -7.671 & $-5.612^{* *}$ & $-5.507 * *$ & $-4.932^{* * *}$ \\
\hline Reverse repo & $(5.307)$ & $(2.561)$ & $(2.034)$ & $(1.486)$ \\
\hline & 9.075 & $5.501^{*}$ & $5.803 * *$ & $5.761^{* * *}$ \\
\hline $\begin{array}{l}\text { Gross value } \\
\text { added }\end{array}$ & $(6.585)$ & $(3.231)$ & $(2.574)$ & $(1.937)$ \\
\hline & 2.800 & 0.692 & 1.492 & 0.843 \\
\hline Inflation & $(1.927)$ & $(1.226)$ & $(1.153)$ & $(0.756)$ \\
\hline & $-0.075 * *$ & -0.013 & $-0.071 * *$ & -0.002 \\
\hline Exchange rate & $(0.034)$ & $(0.034)$ & $(0.032)$ & $(0.019)$ \\
\hline & $-0.787 *$ & -0.205 & $-0.407 *$ & -0.181 \\
\hline Political regime & $(0.368)$ & $(0.279)$ & $(0.233)$ & $(0.154)$ \\
\hline & -0.712 & -0.537 & 0.505 & -0.632 \\
\hline Constant & $(0.834)$ & $(0.756)$ & $(1.269)$ & $(0.663)$ \\
\hline & $\left(633.911^{* *}\right.$ & 16.930 & $231.954^{* * *}$ & $249.432^{* * *}$ \\
\hline & $(25.474)$ & $(63.912)$ & $(66.659)$ \\
\hline Observations & 27 & & & \\
\hline R-squared & 0.986 & 126 & 45 & 135 \\
\hline Robust standard errors in parentheses & 0.674 & 0.911 & 0.799 \\
\hline$* * * \mathrm{p}<0.01, * * \mathrm{p}<0.05, * \mathrm{p}<0.1$ & & & \\
\hline
\end{tabular}

In table 5 we divide the banks into private and public categories. The private model shows the result for private banks. The coefficient of return on assets is -1.92 . We also find a negative and significant effect of business per employee which may have been caused by the operational efficiency in private banks. The macroeconomic factors are found to be insignificant. The public model shows the results for the public banks. The coefficient of return on assets is greater than that of private banks $(-2.72)$. Concentration ratio and business per employee have a negative and significant effect on credit risk. There is a negative and significant effect of repo rate -13.8 and a positive effect of reverse repo rate 15.4 on credit risk. The growth rate of GVA also has a positive and significant (2.99) effect on credit risk.

Table 5. Effect of micro and macro-economic variables on the credit risk of public and private banks

\begin{tabular}{|l|l|l|}
\hline Ownership & PRIVATE & PUBLIC \\
\hline & $\mathbf{( 1 )}$ & $\mathbf{( 2 )}$ \\
\hline VARIABLES & Credit risk & Credit risk \\
\hline Return on Assets & $-1.921^{* * *}$ & $-2.720^{* * *}$ \\
\hline & $(0.232)$ & $(0.691)$ \\
\hline Cost efficiency & 12.993 & 123.560 \\
\hline & $(80.787)$ & $(124.590)$ \\
\hline Age of the bank & $0.013^{* *}$ & $-0.015^{* *}$ \\
\hline & $(0.006)$ & $(0.007)$ \\
\hline
\end{tabular}




\begin{tabular}{|c|c|c|}
\hline \multirow[t]{2}{*}{ Noninterest income } & 0.200 & 0.903 \\
\hline & $(0.280)$ & $(1.078)$ \\
\hline \multirow[t]{2}{*}{ Concentration risk } & -0.000 & $-0.000 * * *$ \\
\hline & $(0.000)$ & $(0.000)$ \\
\hline \multirow[t]{2}{*}{ Size of the bank } & -4.484 & $17.970 * * *$ \\
\hline & $(5.046)$ & $(6.126)$ \\
\hline \multirow[t]{2}{*}{ Size of the bank squared } & 0.645 & $-1.435 * * *$ \\
\hline & $(0.597)$ & $(0.508)$ \\
\hline \multirow[t]{2}{*}{ Credit growth } & 2.653 & -10.925 \\
\hline & $(2.167)$ & $(8.823)$ \\
\hline \multirow[t]{2}{*}{ Business per employee } & $-0.134 * *$ & $-0.259 * * *$ \\
\hline & $(0.059)$ & $(0.099)$ \\
\hline \multirow[t]{2}{*}{ Repo rate } & -1.580 & $-13.876^{* * *}$ \\
\hline & $(0.970)$ & $(3.034)$ \\
\hline \multirow[t]{2}{*}{ Reverse repo rate } & 1.935 & $15.403^{* * *}$ \\
\hline & $(1.209)$ & $(3.845)$ \\
\hline \multirow[t]{2}{*}{ Gross value added } & 0.583 & $2.999 * *$ \\
\hline & $(0.554)$ & $(1.270)$ \\
\hline \multirow[t]{2}{*}{ Inflation } & -0.020 & $-0.055^{*}$ \\
\hline & $(0.016)$ & $(0.030)$ \\
\hline \multirow[t]{2}{*}{ Exchange rate } & -0.086 & $-0.603 * *$ \\
\hline & $(0.113)$ & $(0.259)$ \\
\hline \multirow[t]{2}{*}{ Political regime } & -0.287 & -0.627 \\
\hline & $(0.556)$ & $(0.565)$ \\
\hline \multirow[t]{2}{*}{ Constant } & 19.481 & 13.645 \\
\hline & $(13.998)$ & $(23.672)$ \\
\hline Observations & 162 & 171 \\
\hline R-squared & 0.477 & 0.858 \\
\hline \multicolumn{3}{|c|}{ Robust standard errors in parentheses } \\
\hline \multicolumn{3}{|c|}{$* * * \mathrm{p}<0.01, * * \mathrm{p}<0.05, * \mathrm{p}<0.1$} \\
\hline
\end{tabular}

\section{Dynamic GMM results}

Lagged dependent variables: Credit risk (credit risk $\left.\mathrm{t}_{\mathrm{t}}\right)$ and Return on assets $\left(\mathrm{ROA}_{\mathrm{t}-1}\right)$ are included as lagged variables in the GMM model to check the significance of its impact in determining credit risk.

Table 6 shows the results of our dynamic GMM estimation (equations 2 and 3). We use a group of instrumental variables (IV). The set includes bank-specific micro variables like ROA, cost efficiency of a bank, non-interest income, credit growth, business per employee, age, and the size of the bank. We assume that these bank-specific variables are endogenous to our system, thus we utilize them as instruments in our estimation. We also use a group of exogenous macro-economic variables like repo rate, reverse repo rate, the growth rate of gross value added, wholesale price index, and real effective exchange rate and political regime change (2014).

Table 6 column 1 shows the results of dynamic GMM with micro variables as GMM style and macro variables as IV style. The results suggest the positive and significant coefficient of the lagged value of GNPA. The effect of the repo rate is negative and significant on credit risk. Thus, the increase in the repo rate causes a decrease in credit risk. 
This is also verified by the positive and significant coefficient of the reverse repo rate. The coefficient of political regime is negative and significant of the value -2.68 . It may suggest that the changed regime has helped to reduce the occurrence of credit risk. The size of the bank is negative and significant suggesting that as the size increases the credit risk decreases. The coefficient of non-interest income is also positive and significant like our previous models. Table 6 Column 2 also shows similar results when we drop the squared term of the size of the bank from the equation. The coefficient of repo rate and reverse repo rate drops slightly from -10.72 to -10.25 and 15.877 to 15.02 , respectively.

Table 6. The dynamic effect of a micro and macro-economic variable on credit risk (GMM estimation)

\begin{tabular}{|c|c|c|c|c|c|}
\hline & $(1)^{1}$ & (2) & $(3)^{2}$ & $(4)^{3}$ & (5) \\
\hline VARIABLES & $\begin{array}{l}\text { Credit } \\
\text { risk }\end{array}$ & $\begin{array}{l}\text { Credit } \\
\text { risk }\end{array}$ & $\begin{array}{l}\text { Credit } \\
\text { risk }\end{array}$ & $\begin{array}{l}\text { Credit } \\
\text { risk }\end{array}$ & Credit risk \\
\hline \multirow[t]{2}{*}{ L. Credit risk } & $0.813 * * *$ & $0.816 * * *$ & $1.034 * * *$ & $1.018 * * *$ & $0.877 * * *$ \\
\hline & $(0.123)$ & $(0.142)$ & $(0.105)$ & $(0.286)$ & $(0.069)$ \\
\hline \multirow[t]{2}{*}{ Repo rate } & $-10.720 * * *$ & $-10.250 * * *$ & $-5.442 * * *$ & -6.835 & $-4.719 * * *$ \\
\hline & $(3.852)$ & (3.858) & (1.665) & (4.405) & (1.626) \\
\hline \multirow[t]{2}{*}{ Reverse repo } & $15.877 * *$ & $15.029 * *$ & $8.058 * * *$ & 9.765 & $6.389 * *$ \\
\hline & $(6.156)$ & $(6.156)$ & (2.604) & $(7.232)$ & $(2.956)$ \\
\hline \multirow{2}{*}{$\begin{array}{ll}\text { Gross } & \text { value } \\
\text { added } & \\
\end{array}$} & $2.343^{*}$ & $2.181 *$ & $0.991 *$ & 1.309 & 0.580 \\
\hline & $(1.216)$ & $(1.223)$ & $(0.556)$ & $(1.528)$ & $(0.585)$ \\
\hline \multirow[t]{2}{*}{ Inflation } & 0.021 & 0.023 & $0.021 * * *$ & 0.024 & $0.025 * *$ \\
\hline & $(0.014)$ & $(0.014)$ & $(0.007)$ & $(0.027)$ & $(0.010)$ \\
\hline \multirow[t]{2}{*}{ Exchange rate } & $-0.286^{*}$ & $-0.277^{*}$ & -0.084 & -0.190 & -0.055 \\
\hline & $(0.161)$ & $(0.164)$ & $(0.082)$ & $(0.237)$ & $(0.085)$ \\
\hline \multirow{2}{*}{$\begin{array}{l}\text { Political } \\
\text { regime }\end{array}$} & $-2.686 * *$ & $-2.440 *$ & $-1.222 * *$ & -1.556 & -0.934 \\
\hline & $(1.310)$ & (1.309) & $(0.503)$ & $(1.490)$ & $(0.855)$ \\
\hline \multirow{2}{*}{$\begin{array}{l}\text { L. Return on } \\
\text { Assets }\end{array}$} & 0.399 & 0.203 & -0.658 & -1.629 & \\
\hline & $(0.508)$ & $(0.572)$ & $(0.598)$ & (1.591) & \\
\hline \multirow{2}{*}{$\begin{array}{l}\text { Cost } \\
\text { efficiency }\end{array}$} & 233.599 & 105.445 & -85.379 & -273.508 & -101.401 \\
\hline & (266.237) & $(282.240)$ & (204.898) & $(184.380)$ & $(100.747)$ \\
\hline
\end{tabular}

\footnotetext{
${ }^{1}$ Column 1 \& 2 use the option no level small with GMM style (micro variables) and IV style (macro variables), Lag (2 2) no level small option

${ }^{2}$ Results in Column 3 use GMM style (micro variables) and IV style (macro variables), Lag (2 2) two-step small option.

3 uses lag (2 2) two-step small robust
} 


\begin{tabular}{|c|c|c|c|c|c|}
\hline \multirow{2}{*}{$\begin{array}{l}\text { Age of the } \\
\text { bank }\end{array}$} & 0.370 & 0.533 & $0.031 * * *$ & 0.016 & 0.009 \\
\hline & $(0.442)$ & $(0.496)$ & $(0.010)$ & $(0.025)$ & $(0.010)$ \\
\hline \multirow{2}{*}{$\begin{array}{l}\text { Noninterest } \\
\text { income }\end{array}$} & $1.974 * *$ & $1.747 *$ & -0.278 & 0.104 & \begin{tabular}{|l|l|}
0.167 \\
\end{tabular} \\
\hline & $(0.972)$ & $(1.038)$ & $(0.303)$ & $(0.606)$ & \begin{tabular}{|l|}
$(0.277)$ \\
\end{tabular} \\
\hline \multirow{2}{*}{$\begin{array}{l}\text { Concentration } \\
\text { ratio }\end{array}$} & -0.000 & 0.000 & $0.000^{*}$ & 0.000 & 0.000 \\
\hline & $(0.000)$ & $(0.000)$ & $(0.000)$ & $(0.000)$ & \begin{tabular}{|l|}
$(0.000)$ \\
\end{tabular} \\
\hline \multirow{2}{*}{$\begin{array}{l}\text { Size of the } \\
\text { bank }\end{array}$} & $-24.303 * *$ & $-9.599 *$ & 0.110 & -0.290 & -0.279 \\
\hline & $(10.385)$ & $(4.974)$ & $(0.185)$ & $(1.012)$ & $(0.452)$ \\
\hline \multirow{2}{*}{$\begin{array}{l}\text { Size of the } \\
\text { bank squared }\end{array}$} & 1.692 & & & & \\
\hline & (1.112) & & & & \\
\hline \multirow[t]{2}{*}{ Credit growth } & 4.340 & -0.046 & $14.974 * *$ & 8.250 & 2.540 \\
\hline & $(10.258)$ & (13.055) & $(5.944)$ & $(17.682)$ & $(3.786)$ \\
\hline \multirow{2}{*}{$\begin{array}{l}\text { Business per } \\
\text { employee }\end{array}$} & 0.007 & -0.084 & -0.105 & -0.143 & -0.033 \\
\hline & $(0.163)$ & $(0.242)$ & $(0.095)$ & $(0.184)$ & $(0.078)$ \\
\hline \multirow{2}{*}{$\begin{array}{ll}\begin{array}{l}\text { Return } \\
\text { assets }\end{array} & \text { on } \\
\end{array}$} & & & & & $-1.491 * * *$ \\
\hline & & & & & $(0.252)$ \\
\hline \multirow[t]{2}{*}{ Constant } & & & $-14.235^{* *}$ & -0.699 & -5.353 \\
\hline & & & $(6.145)$ & $(14.645)$ & $\mid(10.553)$ \\
\hline Observations & 259 & 259 & 296 & 296 & 296 \\
\hline Number of id & 37 & 37 & 37 & 37 & 37 \\
\hline $\mathrm{J}$ & 69 & 48 & 91 & 78 & 78 \\
\hline ar2p & 0.860 & 0.921 & 0.816 & 0.721 & 0.978 \\
\hline ar2 & -0.176 & $\begin{array}{l}-0.0993 \\
\end{array}$ & 0.233 & 0.357 & 0.0271 \\
\hline $\operatorname{ar} 1 \mathrm{p}$ & $2.09 \mathrm{e}-07$ & 7.86e-07 & 0.000276 & 0.000832 & $8.73 \mathrm{e}-09$ \\
\hline ar1 & -5.191 & -4.939 & -3.637 & -3.342 & -5.754 \\
\hline Sarganp & 0.139 & 0.00864 & 0.00139 & 0.00299 & 0.00350 \\
\hline Sargan & 64.23 & 55.39 & 117.0 & 96.99 & 96.20 \\
\hline \multicolumn{3}{|c|}{ Standard errors in parentheses } & & & \\
\hline \multicolumn{3}{|c|}{$* * * p<0.01, * * p<0.05, * p<0.1$} & & & \\
\hline
\end{tabular}


The effect of repo rate and reverse repo rate remains the same although the value of the coefficients drops when we use a two-step small option. The effect of the political regime remains negative. However, the coefficients of credit growth and age become significant now and this suggests that as credit growth increases the credit risk will also increase. Column 5 shows the results of robust estimates. The effect of the repo and reverse repo rate remains the same with relatively smaller coefficients (-4.71 and 6.38). The effect of return on assets is highly significant and positive confirming the robustness of results using the dynamic GMM whereas the effect of the lagged variable of return on assets becomes insignificant in columns 1-4. This may suggest that the effect of current values of return on assets has a more significant effect on credit risk in comparison to the previous year's return on assets.

\section{CONCLUSION}

Summarizing the results of empirical analysis, we find that credit risk decreases as banks earn more returns on assets. The results of fixed effects estimation also suggest that the microeconomic variables like cost efficiency, age of the bank, non-interest income, concentration ratio, and credit growth have a positive effect on credit risk. The effect of macroeconomic variables confirms the theory, while repo rate, inflation, exchange rates are negative with credit risk, the relationship is positive with reverse repo rate and gross value added.

The heterogeneity tests show that the effect of return on assets on credit risk is specifically significant and negative for banks located in the west, south, and north region. When comparing the results between the public and private banks, the effect of return on assets is greater for the public sector banks in comparison to private sector banks. The effect of macroeconomic variables like repo and reverse repo rates also becomes insignificant for private sector banks and significant for public sector banks. This may be because public sector banks have to offer several government policies related loans which may increase the sensitivity of credit risk to macroeconomic variables than private banks. The results also consider the endogeneity in the system by considering the endogenous microeconomic variables and exogenous macroeconomic variables. The results of dynamic GMM confirm the robustness of our model. We find significant and negative effects of return on assets on credit risk. Thus, profitable banks can protect themselves from credit risk. The effect of macroeconomic variables like repo rate (-) and reverse repo rate (+) also remain significant like previous results. So, a favorable movement of policy rates can be used to effectively manage credit risk. Interestingly, the effect of the political regime is significant and negative which may suggest that the change in the regime has improved the credit risk of the banking sector in India. This is one of the unique inferences from this study.

\section{REFERENCES}

Arellano, M., \& Bond, S. (1991). Some Tests of Specification for Panel Data: Monte Carlo Evidence and an Application to Employment Equations. The Review of Economic Studies, 58(2), 277. https://doi.org/10.2307/2297968

Athanasoglou, P., Delis, M., \& Staikouras, C. (2006). Determinants of the banks profitability in the south eastern European region. Munich Personnel Repec Archive.https://mpra.ub.uni-muenchen.de/id/eprint/10274

Baranwal, G. (2018). Links between foreign direct investment and human capital formation: Evidence from the manufacturing sector in India, The Journal of International Trade \& 
Economic

Development,

28(2)

137-160, https://doi.org/10.1080/09638199.2018.1508304

Bhattarai, B. P. (2019). Determinants of Commercial Banks' Lending Behavior in Nepal. International Journal of Accounting \& Finance Review, 4(1), 51-60. https://doi.org/10.46281/ijafr.v4i1.338

Bhattarai, B. (2018). Assessing Banks Internal and Macroeconomic Factors as Determinants of Non- Performing Loans: Evidence from Nepalese Commercial Banks. International Journal of Accounting \& Finance Review, 3(1), 13-32. https://doi.org/10.46281/ijafr.v3i1.28

Bielecki, T. R., \& Rutkowski, M. (2004). Credit Risk: Modeling, Valuation and Hedging. Springer Finance. Springer, Berlin, Heidelberg. https://doi.org/10.1007/978-3-66204821-4_1

Curak, M., Poposki, K., \& Pepur, S. (2012). Profitability determinants of the Macedonian banking sector in changing environment. Procedia-Social and Behavioral Sciences, 44, 406-416.

Cai, J., \& Leung, P. (2020). A note on linkage between gross value added and final use at the industry level. Economic Systems Research, 32(3), 428

437.https://doi.org/10.1080/09535314.2020.1718617

Castro, V. (2013). Macroeconomic determinants of the credit risk in the banking system: The case of the GIPSI. Economic Modelling, 31, 672683.https://doi.org/10.1016/j.econmod.2013.01.027

Das, A., \& Ghosh, S. (2007). Determinants of Credit Risk in Indian State-owned Banks: An Empirical Investigation. Economic Issues Journal Articles, 12(2), 27-46.

Digal, S. K., Satpathy, A., \& Behera, S. (2015). Macroeconomic factors affecting the NPAs in the Indian banking system: An empirical assessment. The IUP Journal of Bank Management, 14(1), 57 - 74.

Ghenimi, A., Chaibi, H., \& Omri, M. A. (2017). The effects of liquidity risk and credit risk on bank stability: Evidence from the MENA region. Borsa Istanbul Review, 17(4), 238248. https://doi.org/10.1016/j.bir.2017.05.002

Ghosh, A. (2015). Banking-industry specific and regional economic determinants of nonperforming loans: Evidence from US states. Journal of Financial Stability, 20, 93-104. https://doi.org/10.1016/j.jfs.2015.08.004

Gulati, R., Goswami, A., \& Kumar, S. (2019). What drives credit risk in the Indian banking industry? An empirical investigation. Economic Systems, 43(1), 42-62. https://doi.org/10.1016/j.ecosys.2018.08.004

Guerrero, T. E., Guevara, C. A., Cherchi, E., \& Ortuzar, J. D. (2020). Addressing endogeneity in strategic urban mode choice models. Transportation. https://doi.org/10.1007/s11116-020-10122-y 
Hofmann, B. (2005). Procyclicality: The Macroeconomic Impact of Risk-Based Capital Requirements. Financial Market Portfolio Management, 19, 179-200. https://doi.org/10.1007/s11408-005-3385-1

Khemraj, T., \& Pasha, S. (2009). The Determinants of Non-performing Loans: An Econometric Case Study of Guyana. In Caribbean Centre for Banking and Finance Biannual Conference on Banking and Finance, St. Augustine, Trinidad.

Manab, N. A., Theng, N. Y., \& Md-Rus, R. (2015). The Determinants of Credit Risk in Malaysia. Procedia - Social and Behavioral Sciences, 172, 301-308. https://doi.org/10.1016/j.sbspro.2015.01.368

Misman, F. N., Bhatti, I., Lou, W., Samsudin, S., \& Rahman, N. H. (2015). Islamic Banks Credit Risk: A Panel Study. Procedia Economics and Finance, 31, 75-82. https://doi.org/10.1016/s2212-5671(15)01133-8

Nikolaidou, E., \& Vogiazas, S. D. (2014). Credit Risk Determinants for the Bulgarian Banking System. International Advances in Economic Research, 20(1), 87-102. https://doi.org/10.1007/s11294-013-9444-X

Nkusu, M. (2011). Nonperforming Loans and Macro financial Vulnerabilities in Advanced $\begin{array}{lllll}\text { Economies. } & \text { IMF } & \text { Working }\end{array}$ https://doi.org/10.5089/9781455297740.001

Ranjan, R., \& Dhal, S. (2003). Non-Performing Loans and Terms of Credit of Public Sector Banks in India: an Empirical Assessment. Reserve Bank of India Occasional Paper 24(3), 81-121. Retrieved from https://rbidocs.rbi.org.in/rdocs/Publications/PDFs/60613.pdf

Salas, V., \& Saurina, J. (2002). Credit risk in two institutional regimes: Spanish commercial and saving banks. Journal of Financial Services Research, 22(3), 203-224. https://doi.org/0.1023/a:1019781109676

Tang, D. Y., \& Yan, H. (2006). Macroeconomic Conditions, Firm Characteristics, and Credit Spreads. J Finan Serv Res 29, 177-210.https://doi.org/10.1007/s10693-006-7625-y

Turan, H. (2016). The Weighting of Factors Affecting Credit Risk in Banking. Procedia Economics and Finance, 38, 49-53. https://doi.org/10.1016/s2212-5671(16)30175-7

Valencia, F., \& Laeven, L. (2008). Systemic Banking Crises: A New Database. IMF Working Papers, 08(224), 1. https://doi.org/10.5089/9781451870824.001

Vasishtha, G., \& Rajaraman, I. (2002). Non-Performing Loans of PSU Banks. Economic and Political Weekly, 37(5).

Yurdakul, F. (2014). Macroeconomic Modelling of Credit Risk for Banks. Procedia - Social and Behavioral Sciences, 109, 784-793. https://doi.org/10.1016/j.sbspro.2013.12.544 


\section{APPENDICES}

\section{Appendix A: Descriptive Statistics}

\begin{tabular}{|l|l|l|l|l|l|}
\hline Variable & Obs & Mean & $\begin{array}{l}\text { Std. } \\
\text { Dev. }\end{array}$ & Min & Max \\
\hline Return on Assets (Roa) & 342 & .76 & .81 & -2.33 & 2.5 \\
\hline Non-Interest Income (Nonint) & 342 & 1.22 & .79 & .37 & 6.15 \\
\hline Credit Growth & 342 & .07 & .06 & 0 & .27 \\
\hline Size & 342 & 5.11 & .65 & 3.32 & 7.01 \\
\hline Cost efficiency (Costineffi) & 342 & 0 & 0 & 0 & .01 \\
\hline Credit risk (Credit risk) & 342 & 4.78 & 4.86 & .2 & 27.95 \\
\hline Business per employee (Bperemp) & 333 & 11.74 & 3.7 & 3.91 & 22.2 \\
\hline Concentration Ratio (Conratio) & 342 & .66 & .01 & .65 & .69 \\
\hline Repo rate & 342 & 6.97 & .84 & 5.63 & 8 \\
\hline Reverse repo & 342 & 6.18 & .76 & 4.33 & 7 \\
\hline Age of the firm (Age) & 342 & 77.18 & 33.88 & 7 & 153 \\
\hline Gross Value-added growth rate (Gvagr) & 342 & 7.08 & 1 & 5.4 & 8.9 \\
\hline Wholesale Price index (Wpi) & 342 & 158.1 & 24.38 & 116.3 & 183.2 \\
\hline Real effective exchange rate (REER) & 342 & 111.23 & 4.66 & 103.27 & 119.71 \\
\hline
\end{tabular}

\section{Appendix B: Definition of variables}

\begin{tabular}{|l|l|l|}
\hline Variables & \multicolumn{2}{l|}{ Definition } \\
\hline Micro & Ratio of GNPA to Total Advances & \\
\hline Credit risk & Ratio of Net income to Average total assets & \\
\hline ROA (return on assets) & Ratio of Non-interest income to total assets & \\
\hline NOI (non-interest income) & Ratio of loans to total assets & \\
\hline Credit growth & Ratio of operating expenses to total assets & \\
\hline Cost Inefficiency & $\begin{array}{l}\text { Ratio of top 10 bank's advances to total advances of } \\
\text { banking industry }\end{array}$ & \\
\hline CR10 (Concentration ratio) & Ratio of deposit \& advances to total employees & \\
\hline Business per employee & Log of total assets of the banks & \\
\hline Size & No of years of operations of the banks \\
\hline Age & \multicolumn{2}{|l|}{} \\
\hline Data source: Capitaline database & Repo rate of Reserve bank of India \\
\hline Macro & Reverse repo rate of Reserve bank of India \\
\hline Repo rate & $\begin{array}{l}\text { growth rate of gross value added at factor cost on } \\
\text { constant prices }\end{array}$ & \\
\hline Reverse repo rate & Wholesale price index base year 2004-2005 & \\
\hline GVAgr & $\begin{array}{l}\text { Real effective exchange rate 36-Currency Index } \\
\text { base year 2004-2005 }\end{array}$ & \\
\hline Inflation & &
\end{tabular}




\begin{tabular}{|l|l|l|l|}
\hline Political Regime & $\begin{array}{l}\text { Dummy Variable =1 for years 2014-2018, } 0 \\
\text { otherwise }\end{array}$ & \\
\hline $\begin{array}{l}\text { Data source: Reserve bank of India } \\
\text { \& Indis stat }\end{array}$ & & & \\
\hline
\end{tabular}

\section{Copyrights}

Copyright for this article is retained by the author(s), with first publication rights granted to the journal. This is an open-access article distributed under the terms and conditions of the Creative Commons Attribution license (http://creativecommons.org/licenses/by/4.0/). 